\title{
Anti-receptor Advanced Glycation End Products Decreases Inflammatory Pathways in Retinopathy Diabetics: In vivo Study
}

\author{
Ramzi Amin*, A. K. Ansyori, Riani Erna, Lilianty Fauzi \\ Department of Ophthalmology, Faculty of Medicine, Universitas Sriwijaya, Palembang, Indonesia
}

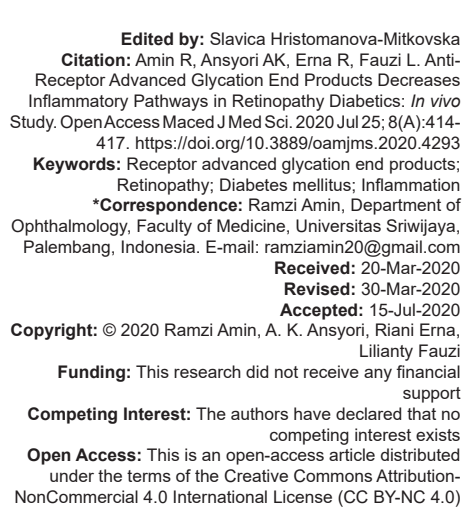

\section{Introduction}

Diabetes mellitus has been being an emerging health problem since the past two decades. The International Diabetes Foundation in 2014 estimated the number of people with type 2 diabetes mellitus worldwide at 387 million, and this number is expected to increase to 552 million by 2030 . Diabetic retinopathy is a serious microvascular complication of diabetes and a major cause of blindness in individuals between ages 30 and 70 years, which is characterized by increased proliferation of blood vessels, vascular occlusion, angiogenesis, loss of pericytes from retinal capillaries, microaneurysms, bleeding, increased retinal capillary permeability, thickening of capillary basal membranes and infarcts that affect the retina of the eye, leading to blindness [1], [2], [3]

\begin{abstract}
Abstract blood vessels, vascular occlusion, angiogenesis, loss of pericytes from retinal capillaries, microaneurysms, retinal

vascularization process which causes a decrease in retinal function on diabetic retinopathy.

MATERIALS AND METHODS: This research was an in vivo experimental study. A total of 30 male Wistar rats $(200 \pm 20 \mathrm{~g})$ were obtained from Eureka Research Laboratory (Palembang, Indonesia). Experimental animals placed in cages under controlled conditions $\left(12 \mathrm{~h}\right.$ of light/dark cycles with temperatures of $22 \pm 1{ }^{\circ} \mathrm{C}$ an humidity of 40-60\%), fed and drank ad libitum. White rats were induced by diabetes mellitus using alloxan at a dose of $120 \mathrm{mg} / \mathrm{kgBW}$, intraperitoneally, accompanied by drinking $10 \%$ glucose solution for 140 days. Furthermore, in ng $/ \mathrm{mL}$, Group 4: Given anti-RAGE $10 \mathrm{ng} / \mathrm{mL}$, and Group 5: Given anti-RAGE $100 \mathrm{ng} / \mathrm{mL}$. Giving anti-RAGE was hydrate, the evacuation of the eye's retinal tissue was then carried out, fixed in a $4 \%$ paraformaldehyde buffer for (he eye's retinal tissue. Evaluation of the expression of nuclear factor- $\kappa \beta$ (NFretinopathy rats. Administration of anti-RAGE showed its potential to suppress NF-kB expression in retinal tissue of

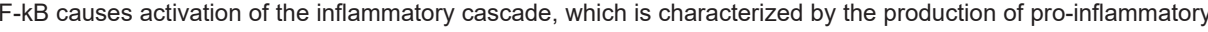
increase in anti-RAGE dose. (he

AIM: This study aimed to find the role of receptor advanced glycation end products (RAGE) inhibition in lowering the
\end{abstract}

CONCLUSION: Anti-RAGE is able to block the inflammatory process, by inhibiting the expression of NF-kB and ICAM-1 in the retinal tissue of diabetics retinopathy in white rats.

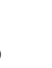

(as


vascular endothelial growth factor, pro-inflammatory cytokines interleukin-1 $\alpha$ (IL-1 $\alpha)$, IL-6, and tumor necrosis factor $\alpha$. This will cause the activation of the inflammatory process which will cause tissue damage accompanied by a wound healing process, in the form of a collagenization and fibrosis process, which in turn, will end in damage to the function of the tissue, in this case retinal tissue [6], [7], [8].

AGE inhibition through RAGE receptor inhibition is a therapeutic promising to inhibit the inflammatory cascade, which forms the basis of the pathophysiology of diabetic retinopathy. This study is a continuation of the previous research, which seeks to see the role of RAGE inhibition in decreasing the vascularization process which causes a decrease in retinal function in the case of diabetic retinopathy. Efforts to explore the mechanism of action pathway continue in this study, where the inflammatory pathway is the target of further exploration [8].

\section{Materials and Methods}

This research is an in vivo experimental study. A total of 30 male Wistar rats $(200 \pm 20 \mathrm{~g})$ were obtained from Eureka Research Laboratory (Palembang, Indonesia). Experimental animals were placed in cages under controlled conditions (12 h of light/dark cycles with temperatures of $22 \pm 1^{\circ} \mathrm{C}$ and humidity of $40-60 \%$ ), fed, and drank ad libitum. All animal treatments and experimental procedures were approved by the Ethics and Humanities Commission of the Faculty of Medicine, Universitas Sriwijaya (No.243/kptfkunsri-rsmh/2019).

White rats were induced to be diabetes mellitus using alloxan at a dose of $120 \mathrm{mg} / \mathrm{kgBW}$, intraperitoneally, accompanied by drinking $10 \%$ glucose solution for 140 days. Furthermore, experimental animals were grouped into five groups (at eight animals per group), Group 1: Normal control, Group 2: Negative control (induced diabetics retinopathy and given intravenous aquadest), Group 3: Given anti-RAGE $1 \mathrm{ng} / \mathrm{mL}$, Group 4: Given anti-RAGE $10 \mathrm{ng} / \mathrm{mL}$, and Group 5: Given anti-RAGE $100 \mathrm{ng} / \mathrm{mL}$. Giving anti-RAGE was done in a single dosage and intravitreal.

After the rats were sacrificed by intraperitoneal injection of $10 \%$ chloral hydrate, the evacuation of the eye's retinal tissue was then carried out, fixed in a $4 \%$ paraformaldehyde buffer for immunohistochemistry examination of the eye's retinal tissue. After the tissue that had been put into the fixation fluid, the next process was dehydrated using alcohol and xylene, then paraffinized and then cut as thick as 5 um using a rotary microtome (Leica). Next, it was placed on coated-object glass. Then, rehydration is carried out on the tissue using xylene and alcohol with a concentration of $96 \%, 90 \%, 80 \%$, and $70 \%$ and rinsed with tap water. The next stage, retrieval antigen was carried out with the HIER (Heat Induced Epitop Retrieval) method, where the slides were put into a citrate buffer solution, then heated at a temperature of $95^{\circ} \mathrm{C}$ for $60 \mathrm{~min}$. Then, NF-kB 1: 700 (Cloud Clone) antibody was painted; ICAM-1 antibody 1: 700 (Cloud Clone), followed by overnight incubation at $4^{\circ} \mathrm{C}$. The next stage was to paint with a secondary antibody, Biotinylated-Horseradish Peroxidase, incubated for $1 \mathrm{~h}$, at room temperature. Next, chromogen was given to the tissue. Furthermore, the dehydration process was again carried out using concentrated alcohol and xylene. The next step was mounting and evaluating the expression of NF-kB and ICAM-1 using Image $J$ Software so that the percentage of NF-kB and ICAM-1 expression would be obtained.

All data were presented as mean \pm standard deviation and all statistical analyzes were performed with the SPSS 25 (IBM) program. One-way ANOVA followed by post hoc analysis was carried out to assess differences in the mean expression levels of each protein. $p<0.05$ was determined as an indication that there were significant differences in the mean levels.

\section{Results}

It is believed that NF- $\mathrm{NB}$ is the main regulator in the activation of pro-inflammatory cytokines. From Table 1, it was clearly stated that negative control group has an increase in NF-kB expression in the retinal tissue of diabetic retinopathy rats. Furthermore, there was higher expression of NF-KB in negative control group which was shown by brownish image in Figure 1. The administration of anti-RAGE showed its potential to suppress NF-kB expression in retinal tissue of diabetic retinopathy white rats as well with an increase of antiRAGE dose from $1 \mathrm{ng} / \mathrm{mL}$ to $100 \mathrm{ng} / \mathrm{mL}$.

Activation of NF-kB causes activation of the inflammatory cascade, which is characterized by the production of pro-inflammatory cytokines, one of which is ICAM-1. Figures 2 and 3 show that in diabetic retinopathy was an increase in the expression of ICAM-1 in the retinal tissue of white rats. Giving antiRAGE can suppress the expression of ICAM-1 along with an increase in anti-RAGE dose.

Table 1: Level of NF-kB expression in retinal tissue retinopathy diabetics

\begin{tabular}{|c|c|c|c|}
\hline S. No. & Group & NF-kB (\%) \pm SD & $p$ value ${ }^{*}$ \\
\hline 1. & Negative control & $70.62 \pm 2.95$ & 0.00 \\
\hline 2. & RAGE 1 ng/mL & $66.98 \pm 5.08$ & 0.00 \\
\hline 3. & RAGE 10 ng/mL & $48.22 \pm 4.27$ & 0.00 \\
\hline 4. & RAGE $100 \mathrm{ng} / \mathrm{mL}$ & $26.66 \pm 3.28$ & 0.00 \\
\hline 5. & Normal & $5.45 \pm 1.31$ & - \\
\hline
\end{tabular}




\section{Discussion}

This study found a significant difference between the treatment groups in diabetic retinopathy white rats that had been given anti-RAGE antibodies against $\mathrm{NF}-\kappa \beta$ expression where in higher dose of

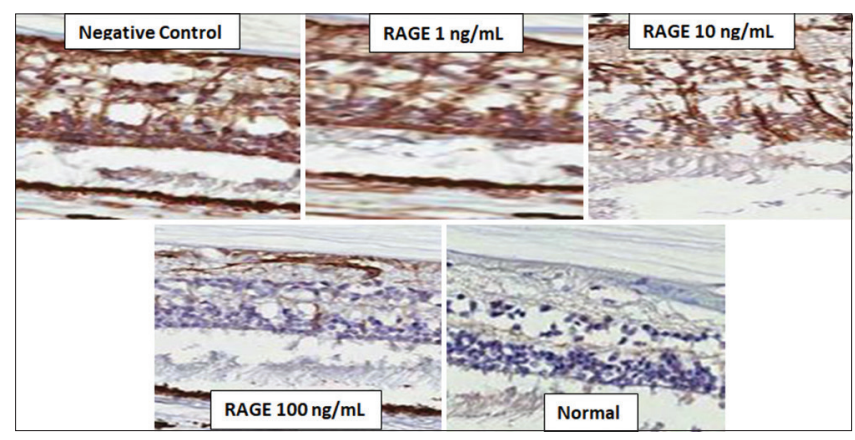

Figure 1: Effect of anti-receptor advanced glycation end products (RAGE) on nuclear factor- $\kappa \beta$ expression in retinal tissue retinopathy diabetics rats. Immunohistochemistry assessment. Normal: Normal group, Negative control: Retinopathy diabetics rats, RAGE $1 \mathrm{ng} / \mathrm{mL}$. RAGE 1, 10, and $100 \mathrm{ng} / \mathrm{mL}$ : Anti-RAGE doses 1, 10, and $100 \mathrm{ng} / \mathrm{mL}$ + Retinopathy diabetics. Magnification $\times 400$

anti-RAGE antibody (100 ng/mL) was more effective than the administration of a dose of $10 \mathrm{ng} / \mathrm{mL}$ because higher dose obtained percentage of $\mathrm{NF}-\kappa \beta$ expression of $26.66 \% \pm 3.28$ while giving $10 \mathrm{ng} / \mathrm{mL}$ of $48.22 \% \pm$ 4.27. AGE-RAGE bonds were able to induce endothelial dysfunction and cause hyperpermeability.

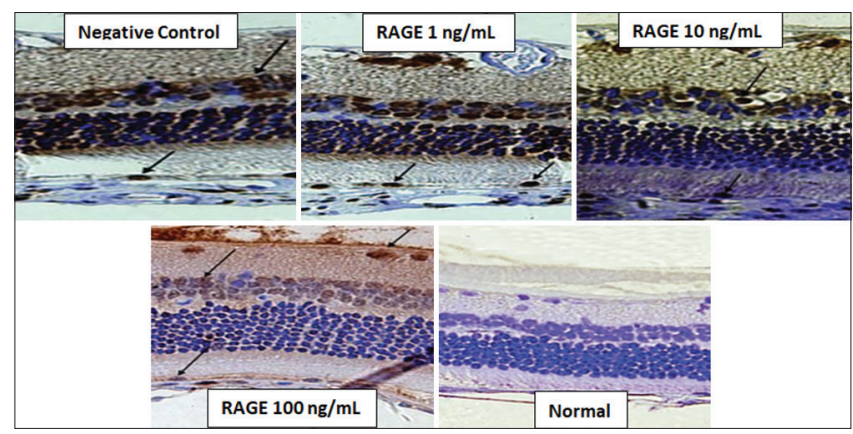

Figure 2: Effect of anti- receptor advanced glycation end products (RAGE) on intercellular adhesion molecule-1 (ICAM-1) expression in retinal tissue retinopathy diabetics rats. Immunohistochemistry assessment. Normal: Normal group, Negative control: Retinopathy diabetics rats, RAGE $1 \mathrm{ng} / \mathrm{mL}$ : RAGE 1, 10, and $100 \mathrm{ng} / \mathrm{mL}$ : Anti-RAGE doses 1,10 , and $100 \mathrm{ng} / \mathrm{mL}+$ retinopathy diabetics. Magnification $\times 400$

At the cellular level, the AGE-RAGE bond could induce nuclear activation and translocation of $N F-\kappa \beta$ (a transcription factor capable of responding to adhesion molecules in endothelial or leukocytes) which would initiate vascular disorders. Activation of $\mathrm{NF}-\kappa \beta$ would also induce activation of pro-inflammatory cytokines. Activation of NF- $\kappa \beta$ also played a role in the occurrence of apoptosis, because it made an increase in the factor of proapoptosis bax (bax-caspase protease pathway). RAGE expression depends on the amount of $N F-\kappa \beta$, which was a positive feedback response to increased RAGE expression through AGE-RAGE interactions. Others study concluded that anti-RAGE treatment in diabetic retinopathy mice could lower pro-inflammatory cytokines such as NF-k $\beta$ and IL1 $\beta$ [3], [9], [10], [11], [12], [13].

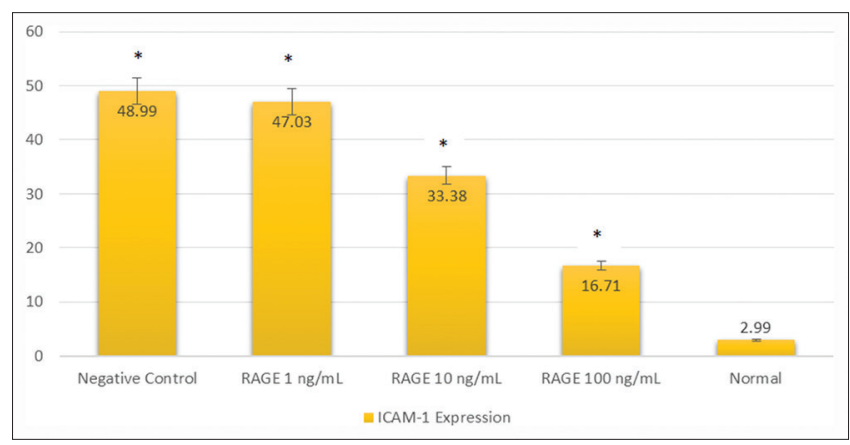

Figure 3: Effect of anti-receptor advanced glycation end products on intercellular adhesion molecule-1 expression in retinal tissue retinopathy diabetics rats. ${ }^{*} p<0.05$ versus normal; ANOVA, post hoc Bonferroni

This research also found a notable difference between the treatment groups in white rats with diabetic retinopathy models who had been given anti-RAGE antibodies to ICAM-1 expression where the dose of anti-RAGE antibody at a dose of $100 \mathrm{ng} / \mathrm{mL}$ was more effective than lower dose $(10 \mathrm{ng} / \mathrm{mL})$ because administration of $100 \mathrm{ng} / \mathrm{mL}$ obtained percentage of ICAM-1 expression of $16.71+3.10$ while administering $10 \mathrm{ng} / \mathrm{mL}$ of $33.38+5.09$. Giving anti-RAGE $100 \mathrm{ng} / \mathrm{mL}$ is considered more effective in reducing ICAM-1 expression.

NF-kB has correlation and relationship with ICAM-1 expression. NF-kB activation activates the inflammatory cascade, which is characterized by secretion of pro-inflammatory cytokines and mobilization of neutrophils at the inflammatory site. The mobilization of neutrophils will cause activation of ICAM-1, which is an adhesion molecule of neutrophils, so as to facilitate the movement and mobilization of neutrophils. The results of this study indicate that an increase in NF- $\mathrm{KB}$ is followed by an increase in ICAM-1 in diabetic retinopathy. Anti-RAGE is able to break the cascade of NF-kB activation through the activation of AGE receptors (RAGE) [14], [15], [16], [17] This study reinforces previous studies also showing the potential of anti-RAGE in preventing angiogenesis activation in diabetics retinopathy. The ability to inhibit angiogenesis in anti-RAGE administration through inhibition of the inflammatory pathway through inhibition of NF-kB and ICAM-1 [8].

\section{Conclusion}

Anti-RAGE is able to block the inflammatory process, by inhibiting the expression of NF-kB and ICAM-1 in the retinal tissue of diabetics retinopathy in white rats. 


\section{Acknowledgment}

The authors would like to express their sincere gratitude to the Clinical Research Unit of Mohammad Hoesin Hospital, Faculty of Medicine, Universitas Sriwijaya, Palembang, Indonesia.

\section{References}

1. Xu J, Chen LJ, Yu J, Wang HJ, Zhang F, Liu Q, et al. Involvement of advanced glycation end products in the pathogenesis of diabetic retinopathy. Cell Physiol Biochem. 2018;48(2):705-17. https://doi.org/10.1159/000491897

2. Mathebula SD. Biochemical changes in diabetic retinopathy triggered by hyperglycaemia: A review. Afr Vision Eye Health. 2018;77(1):a439. https://doi.org/10.4102/aveh.v77i1.439

3. Singh VP, Bali A, Singh N, Jaggi AS. Advanced glycation end products and diabetic complications. Korean J Physiol Pharmacol. 2014;18(1):1-14. https://doi.org/10.4196/ kjpp.2014.18.1.1

PMid:24634591

4. Gaonkar MB, Krishnanda P. Pathogenesis of diabetic retinopathy: Biochemical aspects and therapeutic approaches. Sch J Appl Med Sci. 2015;3(5B):1880-90.

5. McVicar CM, Ward M, Colhoun LM, Guduric-Fuchs J, Bierhaus A, Fleming $\mathrm{T}$, et al. Role of the receptor for advanced glycation endproducts (RAGE) in retinal vasodegenerative pathology during diabetes in mice. Diabetology. 2015;58(5):1129-37. https://doi.org/10.1007/s00125-015-3523-x PMid:25687235

6. Li G, Tang J, Du Y, Lee CA, Kern TS. Beneficial effects of a novel RAGE inhibitor in early diabetic retinopathy and tactile allodynia. Mol Vis. 2011;17:3156-65.

PMid:22171162

7. Tobon-Velasco JC, Cuevas E, Torres-Ramos MA. Receptor for AGEs (RAGE) as mediator of NF-kB pathway activation in neuroinflammation and oxidative stress. CNS Neurol Disord Drug Targets. 2014;13(9):1615-26. https://doi.org/10.2174/187 1527313666140806144831

PMid:25106630
8. Saleh I, Maritska Z, Parisa N, Hidayat R. Inhibition of receptor for advanced glycation end products as new promising strategy treatment in diabetic retinopathy. Open Access Maced J Med Sci. 2019;7(23):3921-4. https://doi.org/10.3889/oamjms.2019.759 PMid:32165929

9. Goh SY, Cooper MK. Clinical review: The role of advanced glycation end products in progression and complications of diabetes. J Clin Endocrinol Metab. 2008;93(4):1143-52. PMid:18182449

10. American Academy of Ophthalmology Retina, Vitreous Panel. Prefered Practice Pattern: Diabetic Retinopathy. San Francisco, CA: American Academy of Ophthalmology; 2016.

11. Haoshen S. Inflammation in the Pathogenesis of Diabetic Retinopathy, Wayne State University Dissertations, 1965; 2018.

12. Zhang W, Liu H, Al-Shabrawey M, Caldwell RW, Caldwell RB. Inflammation and diabetic retinal microvascular complications. J Cardiovasc Dis Res. 2011;2(2):96-103. https://doi. org/10.4103/0975-3583.83035

PMid:21814413

13. Rubsam A, Parikh S, Fort PE. Role of inflammation in diabetic retinopathy. Int J Mol Sci. 2018;19(4):942. https://doi. org/10.3390/ijms19040942

PMid:29565290

14. Abul QF, Khan MS, Safar A, Al-Ghamdi SB, Ahmad I. Understanding biochemical and molecular mechanism of complications of glycation and its management by herbal medicine. In: New Look to Phytomedicine. United States: Academic Press; 2019. p. 331-66. https://doi.org/10.1016/ b978-0-12-814619-4.00013-6

15. Mohammad G, Siddiquei MM, Othman A, Al-Shabrawey M, Abu El-Asrar AM. High-mobility group box-1 protein activates inflammatory signaling pathway components and disrupts retinal vascular-barrier in the diabetic retina. Exp Eye Res. 2013;107:101-9. https://doi.org/10.1016/j.exer.2012.12.009 PMid:23261684

16. Liu $Y$, Costa MB, Gerhardinger C. IL-1beta is upregulated in the diabetic retina and retinal vessels: Cell-specific effects of high glucose and IL-1beta autostimulation. PLoS One. 2012;7(5):e36949. https://doi.org/10.1371/journal.pone.0036949 PMid:22615852

17. Wang J, Li R, Deng Z, Sun Z, Chai L, Guo H, Wang, S. Xueshuantong for injection ameliorates diabetic nephropathy in a rat model of streptozotocin-induced diabetes. Chin J Physiol. 2018;61(6):349-59.

PMid:30580505 